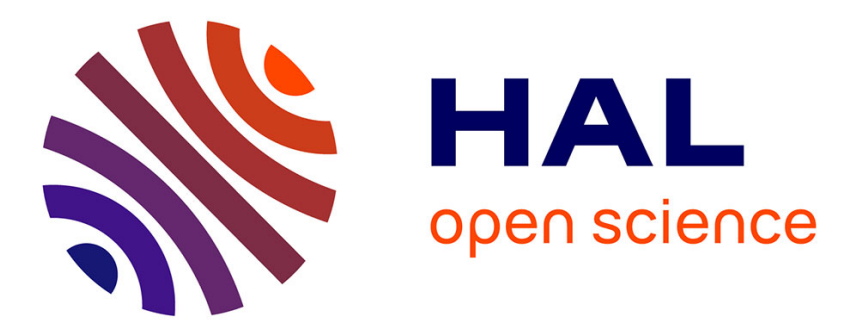

\title{
Access point association in IEEE 802.11 WLAN
}

Loutfi Nuaymi, Jinane El-Sayah

\section{To cite this version:}

Loutfi Nuaymi, Jinane El-Sayah. Access point association in IEEE 802.11 WLAN. ICCTA'04: First International conference on Information and communication technologies : from theory to applications, April 19-23, Apr 2004, Damascus, Syria. pp.211 - 212, 10.1109/ICTTA.2004.1307698 . hal-02127549

\section{HAL Id: hal-02127549 \\ https://hal.science/hal-02127549}

Submitted on 27 May 2019

HAL is a multi-disciplinary open access archive for the deposit and dissemination of scientific research documents, whether they are published or not. The documents may come from teaching and research institutions in France or abroad, or from public or private research centers.
L'archive ouverte pluridisciplinaire HAL, est destinée au dépôt et à la diffusion de documents scientifiques de niveau recherche, publiés ou non, émanant des établissements d'enseignement et de recherche français ou étrangers, des laboratoires publics ou privés. 


\title{
Access Point Association in IEEE 802.11 WLAN
}

\author{
Loutfi Nuaymi - Jinane El-Sayah \\ ENST Bretagne \\ 2, Rue de la Chataigneraie, B.P. 78, Cesson Sévigné 35512 Cedex, FRANCE \\ e-mail: loutfi.nuaymi@enst-bretagne.fr; ;inanesayah@hotmail.com
}

Keywords- WLAN, IEEE 802.11, selection, association, access points

Subject- Here is an extended abstract of the work we would like to present at ICTTA'04 (April 04)

I. Introduction- In IEEE 802.11 [1] Wireless Local Area Networks (WLAN), each wireless station (STA) is associated to one and only one AP (Access Point). The selection of the AP for every wireless stations is an important procedure. A proper choice increases the total capacity of 802.11 WLAN and then leads to efficient use of the available frequency bandwidth. A bad cell selection can cause wireless networks blockings that could be avoided ([3]) as we show it in this paper.

II. Access Point association in WLAN- The two modes of operation defined in the 802.11 standard are described: the Infrastructure and the Ad-Hoc modes, where there is no access points. In this paper, we consider only the infrastructure mode. The procedures that a STA should perform in order to associate with an AP such as scanning, authentication ([5]) and association itself are reminded.

Two scanning procedures are defined: active and passive scanning. A STA, after scanning and making a list of all available APs in the network, will choose an AP to associate with. Which criterion must the STA use to select this AP? This criterion is not specifically stated in 802.11 standard. Different possible method of selection are applied in manufacturers' devices. In most presently-proposed 802.11 products, the STA chooses to associate with the AP that has the best performances in the term of Signal to Noise Ratio (SNR) at the STA geographical position.

We highlight the inconvenients of the currently-used methods of selection of the access points by the wireless stations and try to find and to propose solutions that can rectify this situation.

III. Model and results- We simulate a simple WLAN model for different criterias of AP selection: received power level, received signal-to-intereference ratio and AP-STA distance. Channels are assigned to APs according to 802.11 standard. We remind in the paper APs channel assignment rules.

To calculate the Signal to Noise Ratio (SNR) between each station and each access point, we consider that Noise $=$ sum of the transmitted power of each AP using the same channel * link gain between this $\mathrm{AP}$ and the wireless station.

In the paper, simulation results are commented. For example, Figure 2 shows the AP cclls (callcd Basic Scrvicc Arca or BSA) for a non-uniform distribution of wircless stations, where the best SNR criterion is used. We see that this type of AP selection leads to a cell that has a high concentration of stations. In fact, cells shapes are indendent of the concentration of wireless stations. A WLAN cell with a high number of stations might have quickly bad performances: low data rate and high delays. In the 
paper we propose some solutions such as transmitted power decrease for the AP that has a high data load.

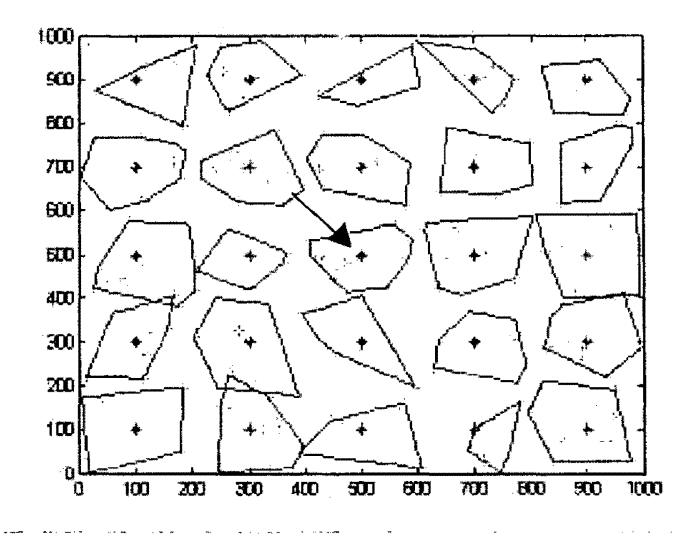

Fig. 2 - For a non-uniform distribution of wireless stations, shape of WLAN cells for an AP selection based on the best received $\mathrm{SNR}$. The central cell has a high number of stations. This leads to bad performances.

\section{Conclusion}

In this paper, we highlight the fact that if the load distribution isn't considered for AP selection in a WLAN, this may lead to inefficient use of the bandwidth.

Some solutions that can rectify this situation are proposed and discussed at the end of the article: power variations and proposing and implementing load distribution algorithms in the 802.11 standard are enhancements that can lead to a greater capacity and better performances. Research papers proposing solutions are mentioned (e.g., [7])

\section{References (used in this abstract)}

[1] IEEE Std 802.11-1999, Part 11: Wireless LAN Medium Access Control (MAC) and Physical Layer (PHY) specifications, 1999

[3] Glenn Judd and Peter Steenkiste. «Fixing 802.11 Access Point Selection». ACM SIGCOMM Computer Communications Review. Volume 32, Number: 3, July 2002.

[5] J. Walker, "Unsafe at any key size: An analysis of the WEP encapsulation", Tech Rep. 03628E, IEEE 802.11 committee, March 2000.

[7] Lan Wang, Zhisheng Niu, Yanfeng Zhu, Hui Deng, Masashi Yano. "Integration of SNR, Load and Time in Handoff. Initiation for Wireless LAN". IEEE PMRC conference, Sept 2003. 